\title{
An unusual cause of chronic diarrhea in an elderly woman
}

\author{
Yaşlı bir kadında nadir bir kronik ishal nedeni \\ Utku Erdem Soyaltın, Deniz Yüce Yıldırım, Bilgin Demir, Ferhat Ekinci, Harun Akar \\ Department of Internal Medicine, Tepecik Training and Research Hospital, İzmir, Turkey
}

\begin{abstract}
Vasoactive intestinal peptide-secreting tumors (VIPomas) are one of the most uncommon types of tumors. Herein we report a 79-year-old woman who was admitted with the complaints of fatigue, weakness, watery diarrhea and dehydration, which was subsequently proven to be from metastatic disease secondary to pancreatic VIPoma. It is recommended for physicians to check the serum vasoactive intestinal peptide levels in prolonged watery diarrhea in the elderly.

Keywords: Chronic diarrhea; vasoactive intestinal peptide; VIPoma.
\end{abstract}

ÖZ

Vazoaktif intestinal peptid salgılayan tümörler (VIPomalar), en nadir görülen tümör tiplerinden biridir. Bu yazıda yorgunluk, halsizlik, sulanmış ishal ve dehidratasyon şikayetleri ile başvuran ve daha sonra bunun pankreas VIPoma'ya ikincil metastatik hastalık olduğu anlaşılan 79 yaşındaki bir kadın hasta sunuldu. Hekimlerin yaşlılarda uzun süreli sulanmış ishalde serum vazoaktif intestinal peptid düzeylerini kontrol etmeleri önerilmektedir.

Anahtar sözcükler: Kronik ishal; vazoaktif intestinal peptit; VIPoma.

Vasoactive intestinal peptide-secreting tumors (VIPomas) are one of the most rare types of tumors originating from pancreatic functioning islet cells. The yearly incidence of these tumors is estimated to be approximately 1 in 10 million individuals in the general population. ${ }^{[1]}$ The definitive diagnosis of VIPoma is established by the laboratory assessment of plasma vasoactive intestinal peptide (VIP) level. ${ }^{[2]}$ Imaging studies also play a role in determining size, location and optimal therapy of the islet cell tumors. The case presented in this report is a female patient who was admitted with the complaints of fatigue, weakness and diarrhea, which was subsequently proven to be from metastatic disease secondary to pancreatic VIPoma.

\section{CASE REPORT}

A 79-year-old woman was admitted to the internal medicine clinic with the complaints of fatigue, weakness and diarrhea. These symptoms have been present for eight months. She denied any history of abdominal pain or fever. Her initial physical examination was negative for abdominal rebound, tenderness, mass or palpable superficial lymph node enlargement. The patient's physical examination remains unremarkable except for severe dehydration. She stated that she had no other medical problems and took no medication. Initial laboratory values revealed hypokalemia $(2.6 \mathrm{mmol} / \mathrm{L})$, hypercalcemia (3.2 mmol/L), hyperglycemia (172 $\mathrm{mg} / \mathrm{dL})$, high blood urea nitrogen $(45 \mathrm{mg} / \mathrm{dL}$ ), high 
serum creatinine $(1.4 \mathrm{mg} / \mathrm{dL})$, and metabolic acidosis on arterial blood gas analysis $(\mathrm{pH}$ : 7.15, bicarbonate level: $6.4 \mathrm{mmol} / \mathrm{L}$ ). Complete blood count, hepatic, coagulation, globulin, prolactin, thyroid and parathyroid profiles were unremarkable. Stool for ova and parasites, culture and sensitivity were negative. Two months before the admission, she was admitted to another center because of chronic diarrhea. Plasma cortisol was found normal, anti-HIV was found negative; computed tomography of the abdomen, endoscopy and colonoscopy were reported as normal at that center. Because of the duration of her symptoms, her dehydration on physical examination and, electrolyte and acidbase imbalances on the laboratory evaluation, we were concerned about a presumptive diagnosis of VIPoma. Due to the presence of possible VIPoma, resultant severe dehydration and, electrolyte and acid-base imbalances, we planned for further examinations. Laboratory findings revealed a high VIP hormone level (562 pg/mL). Magnetic resonance imaging showed a $2.1 \mathrm{~cm}$, well-defined, contrastenhancing lesion involving the pancreatic corpus. Moreover, there were multiple masses scattered throughout the liver (Figure 1 and 2). No other sites of distant metastases were recognized. Computed tomography (CT)-guided fine needle biopsies from the pancreatic and hepatic lesions were obtained and, histopathological and immunohistochemical evaluations were consistent with the neuroendocrine tumor (VIPoma). A written informed consent was obtained from the patient.

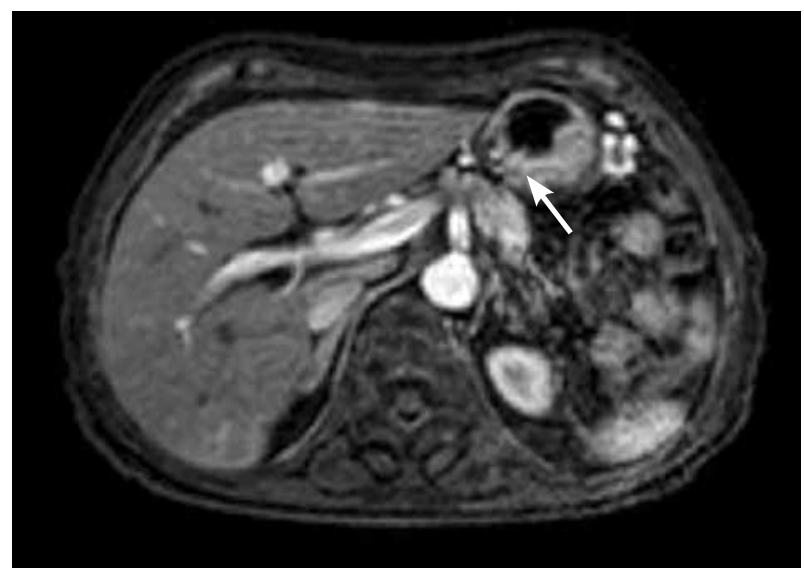

Figure 1. Hypervascular pancreatic mass in the arterial phase contrast.
She was started on intravenous fluids. The patient was placed on a regimen of octreotide for symptomatic control of diarrhea without any improvement. She remained stable after she was started methylprednisolone $(1 \mathrm{mg} / \mathrm{kg})$ and her symptoms resolved immediately.

\section{DISCUSSION}

VIPomas are more frequently diagnosed in women (65\%), with an age onset ranging between two to 83 years. At the time of presentation, $\geq 70 \%$ of the patients already has metastases, and most of these tumors are malignant. ${ }^{[1]}$ Production of large amounts of vasoactive intestinal peptide results in watery diarrhea, hypokalemia and achlorhydria. ${ }^{[3]}$ This condition is called WDHA syndrome (watery diarrhea, hypokalemia, achlorhydria) and was first described by Verner and Morrison in 1958. ${ }^{[3]}$ The case described in the present study occurred in the corpus of pancreas, and presented with WDHA syndrome. The fasting plasma VIP levels, that were $>200 \mathrm{pg} / \mathrm{mL}$ (normal, 0-190 pg/mL), are required to establish the diagnosis. ${ }^{[2]}$ The VIP-immunoreactivity of the present case was markedly positive $(+++)$, and combined with the WDHA syndrome, the diagnosis of VIPoma was confirmed. Most of the pancreatic VIPomas are located in the pancreatic tail (75\%) and are greater than $3 \mathrm{~cm}$ in diameter at the time of the presentation; the neoplastic masses can be easily identified by CT scanning. ${ }^{[10]}$ Magnetic resonance imaging has a reported sensitivity of

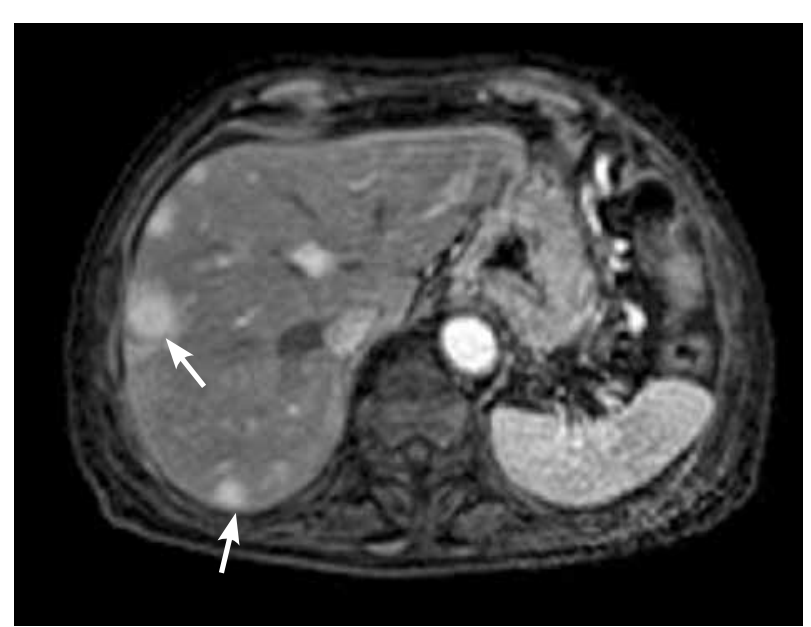

Figure 2. Hypervascular liver metastases in the arterial phase contrast. 
$75-100 \%$ in diagnosing pancreatic neoplasms and can localize neoplasms as small as 1 $\mathrm{cm}$ in diameter. ${ }^{[3]}$ As nearly as $80-90 \%$ of all VIPomas are somatostatin receptor positive; octreoscan scintigraphy is an extremely helpful radiological intervention, although it is rarely used. ${ }^{[4]}$ Intraoperative ultrasonography is useful in the detection of obscure neoplasms that are not visible with the preoperative conventional imaging modalities. ${ }^{[5]}$ We were unable to obtain the patient's previous $\mathrm{CT}$, which was reported as normal.

VIPomas are classical neuroendocrine tumors that stain positively for VIP, chromogranin A, synaptophysin, somatostatin, neuron specific enolase, and cytokeratin..$^{[6]}$ Surgical resection, whenever possible, is the gold standard for patients with primary and secondary (metastatic) VIPoma ${ }^{[5,7]}$ and it has been shown to effectively improve the symptoms and prolong diseasefree survival. ${ }^{[8]}$ Medical (non-surgical) treatment is indicated for symptomatic relief of diarrhea (palliation) in individuals reluctant to surgery or presenting with inoperable metastatic diseases. A somatostatin analogue, octreotide, has been shown to control diarrhea, to reduce VIP levels and to stabilize tumor growth (anti-proliferative properties). ${ }^{[8]}$ Use of glucocorticoids is reserved for patients with diarrhea who are refractory to octreotide. Our patient's symptoms resolved after prednisolone. Because of extensive liver metastasis we started long-acting somatostatin analogue for symptom control. The patient refused chemotherapy. Chemotherapy has been utilized in limited series of unresectable metastatic diseases with varying success rates.

Doxorubicin/streptozotocin is the recommended combination regimen. ${ }^{[9]} \mathrm{A}$ 5-fluorouracil/streptozotocin combination regimen can be considered whenever doxorubicin is contraindicated. ${ }^{[10]}$ Prognosis of VIPoma is largely dependent on tumor grading, staging and surgical resectability. Patients with benign tumors and without distant metastases have extremely favorable prognosis, with a reported five-year survival rate of nearly $95 \% .{ }^{[9]}$ Patients with distant metastases have an estimated five-year survival rate of approximately 60\%. ${ }^{[9]}$ Morbidity/mortality of VIPoma results from untreated WDHA syndrome leading to long-standing dehydration with severe acid-base electrolyte disorder eventually resulting in renal failure, which may cause death, if left untreated.

In conclusion, we report a case of a VIPoma, arising from the corpus of the pancreas with liver metastases. If a patient presents with WDHA syndrome, markedly elevated serum VIP levels, hypervascular lesion and with calcification in the pancreas, VIPoma should be considered in the differential diagnosis.

\section{Declaration of conflicting interests}

The authors declared no conflicts of interest with respect to the authorship and/or publication of this article.

\section{Funding}

The authors received no financial support for the research and/or authorship of this article.

\section{REFERENCES}

1. Ghaferi AA, Chojnacki KA, Long WD, Cameron JL, Yeo CJ. Pancreatic VIPomas: subject review and one institutional experience. J Gastrointest Surg 2008;12:382-93.

2. DelcoreR, FriesenSR. Gastrointestinal neuroendocrine tumors. J Am Coll Surg 1994;178:187-211.

3. Semelka RC, Custodio CM, Cem Balci N, Woosley JT. Neuroendocrine tumors of the pancreas: spectrum of appearances on MRI. J Magn Reson Imaging 2000;11:141-8.

4. Ghaferi AA, Chojnacki KA, Long WD, Cameron JL, Yeo CJ. Pancreatic VIPomas: subject review and one institutional experience. J Gastrointest Surg 2008;12:382-93.

5. Aspestrand F, Kolmannskog F, Jacobsen M. CT, MR imaging and angiography in pancreatic apudomas. Acta Radiol 1993;34:468-73.

6. Ram R, Natanzi N, Saadat P, Eliav D, Vadmal MS. Skin metastasis of pancreatic vasoactive intestinal polypeptide tumor: case report and review of the literature. Arch Dermatol 2006;142:946-7.

7. Bieligk SC, Jaffe BM. VIPoma. In: Percopo V, Kaplan EL, editors. GEP and Multiple Neuroendocrine Tumors. Padua (Padova): Piccin Nuova Libraria S.p.A; 1996. p. 357-69.

8. Brentjens R, Saltz L. Islet cell tumors of the pancreas: the medical oncologist's perspective. Surg Clin North Am 2001;81:527-42.

9. Soga J, Yakuwa Y. Vipoma/diarrheogenic syndrome: a statistical evaluation of 241 reported cases. J Exp Clin Cancer Res 1998;17:389-400.

10. Moertel CG, Lefkopoulo M, Lipsitz S, Hahn RG, Klaassen D. Streptozocin-doxorubicin, streptozocinfluorouracil or chlorozotocin in the treatment of advanced islet-cell carcinoma. N Engl J Med 1992;326:519-23. 